\title{
Investigação genética da surdez hereditária: mutação do gene da Conexina 26
}

\section{Genetic investigation of hereditary deafness: Connexin 26 gene mutation}

\author{
Paula Michele da Silva Schmidt ${ }^{1}$,Tania Maria Tochetto ${ }^{2}$
}

\begin{abstract}
RESUMO
Nos últimos anos houve grande progresso na localização de genes associados à deficiência auditiva hereditária, possibilitando diagnósticos cada vez mais precisos e precoces. Mutações no gene da Conexina 26 (GJB2 - Cx26) causam deficiência auditiva. Pela facilidade e benefício do rastreamento de mutações no gene GJB2, o teste genético está se tornando um importante recurso na saúde pública. O objetivo foi realizar pesquisa bibliográfica sobre a mutação do gene da Conexina 26 e sua influência na audição. Foi realizado um levantamento bibliográfico por meio de busca eletrônica utilizando os descritores: perda auditiva, genética, triagem genética, Conexina 26, nas bases de dados MEDLINE, SciELO e LILACS, desde a década de 90 até os dias atuais. Concluiu-se que a mutação $35 \mathrm{delG}$ da Conexina 26 está potencialmente vinculada a alguns casos de perda auditiva não esclarecida. A pesquisa desta mutação poderia ser incluída na bateria de exames de investigação etiológica da surdez indeterminada, uma vez que esclarece a etiologia de alguns casos e a sua identificação possibilita o aconselhamento genético.
\end{abstract}

Descritores: Perda auditiva/genética; Surdez/genética; Triagem genética; Mutação; Conexinas/genética

\section{INTRODUÇÃO}

O estudo das causas genéticas de surdez avançou significativamente nos últimos anos. Genes relacionados à surdez têm sido identificados e isolados.

Muitos pacientes com perda auditiva neurossensorial de causa indefinida podem apresentar alterações cromossômicas determinantes de sua patologia que não foram pesquisadas. Mutações em alguns desses genes podem causar deficiência auditiva de forma isolada, as chamadas formas não-sindrômicas ou configurar diversos quadros sindrômicos de surdez associada a outras anomalias ${ }^{(1)}$.

Exames simples e acessíveis, capazes de investigar as mutações mais comuns associadas a perdas auditivas tornaram possível o esclarecimento etiológico de alguns casos ${ }^{(2)}$.

Calcula-se que mais de 100 genes estejam potencialmente envolvidos na deficiência auditiva não-sindrômica ${ }^{(3)}$.

O estudo da surdez de origem genética enumera possibilidades diagnósticas cada vez mais amplas. No final de 1997,

Trabalho realizado no Programa de Pós-Graduação em Distúrbios da Comunicação Humana da Universidade Federal de Santa Maria - UFSM - Santa Maria (RS), Brasil.

(1) Pós-graduanda em Distúrbios da Comunicação Humana pela Universidade Federal de Santa Maria - UFSM - Santa Maria (RS), Brasil.

(2) Doutora, Professora Associada do Departamento de Fonoaudiologia da Universidade Federal de Santa Maria - UFSM - Santa Maria (RS), Brasil. Endereço para correspondência: Paula Michele da Silva Schmidt. R. Silva Jardim, 1854/42, Centro, Santa Maria - RS, CEP 97010-492. E-mail: paulamsschmidt@yahoo.com.br

Recebido em: 14/4/2008; Aceito em: 21/7/2008 foi isolado e clonado o gene GJB2, que codifica a proteína Conexina 26, o primeiro gene nuclear relacionado à surdez não-sindrômica ${ }^{(4)}$.

Uma mutação específica deste gene, a 35deIG (deleção de uma guanina na posição 35 do gene), está envolvida em $70 \%$ dos casos de surdez de herança autossômica recessiva. Acredita-se hoje que mutações no gene da Conexina 26 sejam responsáveis por 10 a $20 \%$ de todas as perdas auditivas neurossensoriais ${ }^{(5)}$.

A alta proporção de perda auditiva neurossensorial nãosindrômica, ocasionada pela mutação no gene Conexina 26, indica a relevância do estudo molecular desse gene na fisiologia da audição(6).

Diante do exposto, este estudo teve como objetivo efetuar uma pesquisa bibliográfica sobre a perda auditiva genética resultante da mutação do gene que codifica a Conexina 26.

\section{REVISÃO DE LITERATURA}

No Quadro 1 são apresentados os principais estudos referentes às mutações genéticas relacionadas à perda auditiva genética hereditária não-sindrômica.

\section{DISCUSSÃO}

Recentes e contínuos avanços no campo da genética molecular têm proporcionado, cada vez mais, a identificação de genes responsáveis pelas formas hereditárias de surdez, permitindo sua detecção precoce $^{(7)}$. 
Quadro 1. Principais estudos referentes às mutações genéticas relacionadas à perda auditiva genética hereditária não-sindrômica

\begin{tabular}{|c|c|c|c|}
\hline Autor (data) & Objetivo & Sujeitos & Achados \\
\hline $\begin{array}{l}\text { Estivill et al. } \\
\text { (1998) }\end{array}$ & $\begin{array}{l}\text { Rastreamento de mutações } \\
\text { do gene GJB2 }\end{array}$ & $\begin{array}{l}\text { Famílias com surdez não-sindrômica (Medi- } \\
\text { terrâneo) }\end{array}$ & $\begin{array}{l}49 \% \text { dos casos com padrão de herança au- } \\
\text { tossômico recessivo apresentaram mutações } \\
\text { no gene GJB2 }\end{array}$ \\
\hline $\begin{array}{l}\text { Sartorato et } \\
\text { al. }(2000)\end{array}$ & $\begin{array}{l}\text { Rastreamento molecular da } \\
\text { mutação 35delG }\end{array}$ & 602 neonatos & $\begin{array}{l}\text { Portadores da mutação 35delG: 0,97\%, } \\
\text { sendo 1:103 heterozigotos }\end{array}$ \\
\hline $\begin{array}{l}\text { Abe et al. } \\
(2000)\end{array}$ & $\begin{array}{l}\text { Rastreamento de mutações } \\
\text { do gene GJB2 }\end{array}$ & $\begin{array}{l}\text { Indivíduos com surdez não-sindrômica de } \\
\text { herança autossômica recessiva (Japão) }\end{array}$ & Mutação mais frequente: $235 \mathrm{delC}$ \\
\hline $\begin{array}{l}\text { Van Laer et } \\
\text { al. (2001) }\end{array}$ & $\begin{array}{l}\text { Rastreamento molecular da } \\
\text { mutação 35delG }\end{array}$ & $\begin{array}{l}53 \text { a } 560 \text { indivíduos (recém-nascidos, crian- } \\
\text { ças e adultos), normo-ouvintes (EUA, afro- } \\
\text { americanos, Inglaterra, França, Egito) }\end{array}$ & $\begin{array}{l}\text { Prevalência da mutação 35delG: 0\% (EUA, } \\
\text { afro-americanos, Inglaterra, França e Egito); } \\
4,4 \% \text { (Estônia) }\end{array}$ \\
\hline $\begin{array}{l}\text { Oliveira et } \\
\text { al. (2002) }\end{array}$ & $\begin{array}{l}\text { Rastreamento de mutações } \\
\text { do gene GJB2 }\end{array}$ & $\begin{array}{l}36 \text { famílias com surdez neurossensorial } \\
\text { não-sindrômica e } 26 \text { indivíduos com surdez } \\
\text { (fatores ambientes não foram totalmente } \\
\text { excluídos) }\end{array}$ & $\begin{array}{l}\text { Mutação presente: } \\
\text { - em } 22 \% \text { das famílias com surdez neuros- } \\
\text { sensorial não-sindrômica e } \\
\text { - em } 11 \% \text { dos indivíduos em que os fatores } \\
\text { ambientais não foram excluídos }\end{array}$ \\
\hline $\begin{array}{l}\text { Pfeilsticke } \\
\text { et al. (2004) }\end{array}$ & $\begin{array}{l}\text { Investigação da presença } \\
\text { das mutações 35delG/GJB2, } \\
\text { A1555G/12SeRNA e A7445G/ } \\
\text { tRNASer }\end{array}$ & $\begin{array}{l}75 \text { pacientes com surdez de etiologia in- } \\
\text { definida }\end{array}$ & $\begin{array}{l}\text { Encontraram seis mutações diferentes: } \\
\text { - quatro 35delG/GJB2, } \\
\text { - uma A7445G/tRNASer e } \\
\text { - uma W172X/GJB2 (ainda não descrita) }\end{array}$ \\
\hline $\begin{array}{l}\text { Piatto et al. } \\
(2004)\end{array}$ & $\begin{array}{l}\text { Rastreamento molecular da } \\
\text { mutação 35delG. }\end{array}$ & $\begin{array}{l}\text { Sujeitos com surdez neurossensorial não- } \\
\text { sindrômica }\end{array}$ & Prevalência: $12,12 \%$ em heterozigotos \\
\hline $\begin{array}{l}\text { Fitzgerald } \\
\text { et al. (2004) }\end{array}$ & $\begin{array}{l}\text { Rastreamento molecular da } \\
\text { mutação 35delG }\end{array}$ & 2089 neonatos (Nova lorque, EUA) & Prevalência: $1,29 \%$ \\
\hline $\begin{array}{l}\text { Piatto et al. } \\
(2005)\end{array}$ & $\begin{array}{l}\text { Rastreamento molecular da } \\
\text { mutação 35delG }\end{array}$ & 223 recém-nascidos & $\begin{array}{l}\text { - Identificados } 5 \text { heterozigotos } \\
\text { - Prevalência da mutação 35delG: 2,24\% }\end{array}$ \\
\hline $\begin{array}{l}\text { Marlin et al. } \\
(2005)\end{array}$ & Correlação genótipo-fenótipo & $\begin{array}{l}256 \text { pacientes surdos com presença da } \\
\text { mutação do gene GJB2 ou com mutação } \\
\text { GJB2 associada à deleção GJB6 }\end{array}$ & $\begin{array}{l}\text { - Identificaram } 29 \text { diferentes mutações do } \\
\text { gene GJB2, sendo } 3 \text { ainda não descritas. - } \\
\text { Frequência da mutação 35delG: } \\
69 \% \\
\text { - Comparação da perda auditiva entre irmãos } \\
\text { em } 49 \text { famílias: severidade da surdez variável } \\
\text { em } 18 \text { famílias (37\%) }\end{array}$ \\
\hline $\begin{array}{l}\text { Rabionet et } \\
\text { al. (2006) }\end{array}$ & $\begin{array}{l}\text { Rastreamento de mutações } \\
\text { do gene GJB2 }\end{array}$ & $\begin{array}{l}\text { Uma família cubana com surdez neuros- } \\
\text { sensorial congênita não-sindrômica de grau } \\
\text { profundo }\end{array}$ & $\begin{array}{l}\text { Descreveram nova mutação autossômica } \\
\text { dominante: G21R }\end{array}$ \\
\hline $\begin{array}{l}\text { Bernardes } \\
\text { et al. (2006) }\end{array}$ & $\begin{array}{l}\text { Rastreamento molecular da } \\
\text { mutação 35delG }\end{array}$ & $\begin{array}{l}32 \text { crianças candidatas e usuárias de im- } \\
\text { plante coclear com surdez supostamente } \\
\text { idiopática }\end{array}$ & $\begin{array}{l}\text { - Homozigose em } 12 \% \text { dos casos } \\
\text { - Heterozigose em } 11 \% \text { dos casos }\end{array}$ \\
\hline $\begin{array}{l}\text { Oliveira et } \\
\text { al. (2007) }\end{array}$ & $\begin{array}{l}\text { Rastreamento molecular da } \\
\text { mutação 35delG }\end{array}$ & $\begin{array}{l}1856 \text { recém-nascidos em } 10 \text { cidades de } \\
\text { diferentes regiões do Brasil }\end{array}$ & $\begin{array}{l}\text { As diferenças não foram significativas entre } \\
\text { as regiões }\end{array}$ \\
\hline
\end{tabular}

Nos países desenvolvidos, a perda auditiva neurossensorial acomete um em cada 1.000 recém-nascidos na fase pré-lingual. Em cerca de $60 \%$ dos casos a etiologia da perda auditiva é hereditária, $30 \%$, adquirida e $10 \%$, de etiologia idiopática ${ }^{(8-9)}$. Dentre as causas hereditárias, as formas sindrômicas representam 30\% dos casos de perda auditiva em crianças e as formas não-sindrômicas, cerca de $70 \%$ dos casos ${ }^{(10)}$. Dentre as formas de herança, a autossômica recessiva é a mais frequente (75\%-85\%), seguida pela dominante (12-13\%) e ligada ao X ou mitocondrial por 2\%-3\% dos casos de perda auditiva nãosindrômica ${ }^{(8-9)}$.

A perda auditiva decorrente da mutação do gene GJB2 se caracteriza por ser pré-lingual, não-progressiva, profunda, com limiares altos em todas as frequências ${ }^{(11)}$. Nos casos em que a forma de herança é autossômica recessiva, para que se expresse a surdez, é necessário que o indivíduo herde dois alelos mutados, sendo um do pai e outro da mãe, isto é, que seja homozigoto. Sendo assim, há impossibilidade da Conexina 26 ser codificada pelo gene GJB2 alterado. Nos casos de heterozigose, quando o paciente apresentar a mutação em apenas um dos alelos, é possível que o outro alelo codifique a proteína, isso implica em um menor número de Conexina 26 codificada $^{(12)}$.

O gene GJB2, localizado no braço longo do cromossomo 13 (13q11-12), que codifica a proteína Conexina 26, é o primeiro gene indicado para análise molecular em famílias que apresentam perda auditiva neurossensorial ${ }^{(13)}$ e está envolvido tanto nas formas dominantes quanto recessivas de surdez nãosindrômica. Mutações no gene GJB2 são responsáveis por até $50 \%$ das perdas auditivas recessivas pré-linguais ${ }^{(14)}$. Uma mutação específica deste gene, a 35delG é a mais frequente e trata-se da perda de uma base guanina da sequência de DNA 
deste gene na posição 35 . A pesquisa da mutação 35 delG na etiologia da surdez é muito importante, pois 2 a $4 \%$ dos indivíduos são portadores dessa mutação, ou seja, são heterozigotos. Esta mutação corresponde de 75 a $80 \%$ daquelas encontradas no gene GJB2 $2^{(15)}$.

Em um rastreamento molecular da mutação $35 \mathrm{delG}$ em crianças candidatas e usuárias de implante coclear que tiveram a surdez diagnosticada como supostamente idiopática foi encontrada homozigose em $12 \%$ dos casos, sendo considerada esta a causa da surdez, e heterozigose em $11 \%$ dos casos. A mutação $35 \mathrm{delG}$ em heterozigose não diagnostica a causa da surdez, apenas comprova que o paciente é portador da mutação. Portanto, neste estudo foi possível diagnosticar como genética a causa da surdez em uma parcela significativa de crianças ${ }^{(12)}$.

A Conexina 26 está associada à comunicação celular, relacionando-se aos chamados gap junctions (junções intercelulares), canais que têm como função promover a remoção rápida de íons potássio das células ciliadas sensoriais permitindo a reciclagem de íons potássio nos fluidos cocleares, a fim de se manter a capacidade auditiva ${ }^{(6)}$, realizando assim um papel crucial na função fisiológica relacionada à homeostase iônica coclear e no processo fisiológico do potencial endococlear ${ }^{(16)}$. Pela formação desse canal intercelular, é que estas proteínas foram denominadas de Conexinas, sendo sua produção regulada pelo gene Conexina $26^{(6)}$. Portanto, mutações no gene da Conexina 26 ocasionam alterações na estrutura protéica dessas junções prejudicando a remoção dos íons potássio das células ciliadas e impedindo sua excitação a novos estímulos sonoros, resultando em perda auditiva ${ }^{(17)}$.

A Conexina 26 influencia a função da estria vascular, membrana basilar, limbus e proeminência espiral da cóclea humana. A perda de função desta Conexina neste complexo contribui para alterar a permeabilidade das células de suporte e fibroblastos do órgão de Corti, permitindo que o potássio presente em grande concentração no ducto coclear se difunda no órgão, modifique o transporte e permeabilidade deste íon nas sinapses das células ciliadas e acarrete a perda auditiva ${ }^{(18)}$.

Avaliação microscópica do osso temporal de um paciente com surdez que apresentava mutação 35 delG heterozigótica revelou ausência de degeneração neural, células do gânglio espiral preservadas, degeneração quase total das células ciliadas do órgão de Corti, membrana tectorial desconectada, agenesia da estria vascular e um grande cisto na escala média na região da estria vascular ${ }^{(19)}$.

Nos países em desenvolvimento, ainda há poucos estudos sobre a prevalência da perda auditiva genética. No Brasil, foi determinada a prevalência de $0,97 \%$ de portadores da mutação $35 \mathrm{delG}$, aproximadamente 1:103 heterozigotos, em um rastreamento realizado em 620 neonatos, na região de Campinas (SP) ${ }^{(20)}$. Em outro estudo brasileiro foram encontradas mutações no gene GJB2 em 22\% das famílias com surdez neurossensorial não-sindrômica. A mutação 35delG foi identificada em 84,2\% dos alelos. Mais uma vez fica claro que a análise molecular desse gene em pacientes com perda auditiva não associada a quadros sindrômicos pode ser o primeiro passo na determinação das causas de perda auditiva em nosso país. Isto é particularmente verdadeiro para os casos familiais, nos quais a frequência de mutações nesse gene foi de $50 \%$ e também para os casos esporádicos, entre os quais a frequência foi de pouco mais de $11 \%$ (aproximadamente 1:9)(21).

Outro estudo nacional, com 223 recém-nascidos evidenciou a mutação $35 \mathrm{delG}$ em cinco heterozigotos, sendo portanto a prevalência de 2,24\% $(1: 44,6)^{(22)}$. Esse resultado é concordante com estudos já realizados e descritos na literatura em diferentes populações. A prevalência de portadores, em amostras de 53 a 560 indivíduos (recém-nascidos, crianças ou adultos), com audição normal, variou de $0 \%$ (EUA, afro-americanos, Inglaterra, França, Egito) a 4,4\% (Estônia) ${ }^{(23)}$. No estado de Nova Iorque (EUA), em rastreamento realizado em uma população de 2089 neonatos, foi encontrada a prevalência de $1,29 \%$ de portadores da mutação $35 \mathrm{delG}^{(24)}$. Entre as famílias com perda auditiva não-sindrômica estudadas no Mediterrâneo 49\% dos casos com padrão de herança autossômico recessivo apresentaram mutações no gene GJB2. Nessa população, porém, essas mutações foram observadas numa proporção muito maior de casos esporádicos $(37 \%)^{(25)}$.

De acordo com a literatura, as análises do gene da Conexina 26 , em pacientes com perda auditiva demonstram heterozigose em aproximadamente 10 a $42 \%$ dos casos, a despeito de a maioria das mutações, especialmente a mutação 35delG, ter caráter recessivo ${ }^{(26)}$. Em sintonia com esses dados estão os resultados encontrados em pacientes com perda auditiva neurossensorial não-sindrômica, no Hospital de Base de São José do Rio Preto, em que a prevalência foi de $12,12 \%$ em heterozigotos ${ }^{(27)}$.

Em outras investigações brasileiras a prevalência de indivíduos heterozigotos, com perda auditiva foi de $6,45 \%{ }^{(21)}$ e $2,66 \%{ }^{(24)}$, inferior à referida pela literatura, talvez por diferenças na amostra ou pelas características étnicas e regionais da população brasileira ${ }^{(21)}$.

Para verificar se a composição étnica das diferentes regiões do Brasil causa variação da frequência da mutação 35delG, um rastreamento desta mutação realizado em 1.856 recém nascidos de dez cidades em diferentes regiões do Brasil. A mutação $35 \mathrm{delG}$ foi encontrada em 25 indivíduos $(1,35 \%$, 1:74). A frequência da mutação foi de 1:47 no Norte, 1:64 no Sudeste, 1:85 no Sul e 1:124 no Nordeste, mas estas diferenças não foram significativas ${ }^{(28)}$.

Uma vez que a perda auditiva ocasionada pela mutação 35 delG se manifeste quando existe a mutação em ambos os alelos (homozigose), na maior parte dos casos caracterizando transmissão autossômica recessiva, são necessárias análises mais abrangentes do gene da Conexina 26, a fim de distinguir os pacientes heterozigotos que apresentam déficit auditivo (prevalência em 10 a $42 \%$ dos casos) ${ }^{(5)}$ daqueles heterozigotos normais (portadores saudáveis, ou seja, indivíduos com a mutação em apenas um alelo, mas com audição normal, cuja prevalência é estimada em 2 a $4 \%$ da população sem déficit auditivo) ${ }^{(29)}$.

Esses dados apóiam o uso de testes genéticos para identificar a mutação 35delG, já que possibilita o diagnóstico de portadores saudáveis, de homozigotos ou de portadores da mutação $35 \mathrm{delG}$ com perda auditiva, em uma grande proporção de casos. Testes genéticos podem complementar a Triagem Auditiva Neonatal, considerando que são simples, rápidos, de fácil execução e de baixo custo ${ }^{(2,30)}$. 
Os recém-nascidos que apresentarem heterozigose pelo teste genético deverão ter acompanhamento audiológico seriado, pois esses podem portar a mutação $35 \mathrm{delG}$ com ou sem perda auditiva.

Considerando uma família na qual tenham sido diagnosticadas, em uma criança com surdez, mutações nos dois alelos do gene GJB2, o risco de recorrência na irmandade é estimado em $25 \%$. Entretanto, o grau de perda auditiva de um novo indivíduo afetado não é previsível, uma vez que existem casos de famílias com expressividade variável, ou seja, em que indivíduos com o mesmo genótipo têm fenótipos diferentes com relação à audição. Por sua vez, o risco de recorrência familial na situação de um casal ouvinte com um filho afetado por surdez não-sindrômica sem história de perda auditiva na família e sem mutações no gene GJB2 foi estimado em 14\%, um pouco inferior ao risco estimado nos casos em que nenhum rastreamento molecular é realizado $(17 \%)^{(31)}$. Na situação em que um dos cônjuges é ouvinte e portador de mutação no gene GJB2, e o outro, também ouvinte, tem os dois alelos deste gene normais, o risco de virem a gerar um filho com surdez seria inferior a $0,075 \%{ }^{(30)}$.

Desta forma, apesar da identificação destas anomalias fornecer informações importantes para aqueles que já apresentam perda auditiva, é necessária cautela em qualquer afirmação referente aos pacientes que possuem a mutação genética sem doença evidente. No entanto, existindo o risco de $25 \%$ de recorrência do genótipo, fica clara a importância do aconselhamento genético à família do paciente com a mutação ${ }^{(3)}$.

Os estudos indicam, portanto, que nos casos de surdez com recorrência familial ou mesmo nos de origem indefinida a primeira hipótese que pode ser testada é a da existência de mutações no gene da Conexina 26, em particular a 35delG, que é considerada a mutação mais frequente ${ }^{(32)}$.

Não foi determinada ainda uma correlação entre a mutação 35 delG e a severidade ou progressão da perda auditiva ${ }^{(3)}$. Casos de perda auditiva tardia, em indivíduos com mutações do gene da Conexina 26, confirmados apenas na terceira década de vida, também já foram relatados. Além disso, diferentes graus de surdez podem ser observados em indivíduos de uma mesma família com o mesmo genótipo ${ }^{(3,33)}$.

Características clínicas de 256 pacientes com perda auditiva e presença de mutação do gene GJB2 ou com mutação do GJB2 associada à deleção GJB6 foram analisadas e correlacionadas ao genótipo dos pacientes. Foram identificadas 29 diferentes mutações do gene GJB2, mas a frequência da $35 \mathrm{delG}$ foi de $69 \%$. Foram encontradas três mutações do gene GJB2 ainda não descritas. Em 49 famílias, a perda auditiva foi comparada entre irmãos com genótipos semelhantes, e houve variabilidade em termos de severidade em 18 famílias (37\%). Os autores concluíram que o genótipo pode afetar severamente a surdez, mas o ambiente e outros fatores genéticos podem influir na severidade e evolução da perda auditiva ${ }^{(34)}$.

Apesar de o genótipo não predizer a condição auditiva, homozigotos para $35 \mathrm{delG}$ têm incidência de perda auditiva pré-lingual significativa: 26 a $30 \%$ terão surdez severa e outros 30 a $57 \%$ profunda. Perda auditiva severa a profunda afeta aproximadamente 1 para 1000 neonatos. Em 50\% des- tas crianças, a perda é presumivelmente genética, herdada de forma autossômica recessiva ${ }^{(18-19)}$.

Além da 35delG, primeira mutação descrita no gene da Conexina 26, mais de 50 outras mutações já foram relatadas ${ }^{(35)}$.

As mutações que causam perda auditiva de herança recessiva são mais comuns e poucas mutações de herança dominante são associadas à perda auditiva ${ }^{(36)}$.

Identificar as mutações possíveis do gene da Conexina 26 pode ajudar a entender o relacionamento entre este gene e o fenótipo da surdez ${ }^{(37)}$. Estudo descreveu uma nova mutação autossômica dominante do gene GJB2, a mutação G21R, identificada em cinco indivíduos de três gerações de uma família cubana, que apresentavam perda auditiva neurossensorial congênita não-sindrômica de grau profundo ${ }^{(37)}$.

A mutação GJB2 foi analisada em japoneses com perda auditiva não-sindrômica de herança autossômica recessiva, confirmaram que esta mutação é uma causa importante de perda auditiva nesta população. Foram relatadas três mutações mais frequentes, sendo a $235 \mathrm{delC}$ a de maior prevalência (73\%). A mutação 35delG, que é a mutação mais comum deste gene, não foi encontrada neste estudo. Os dados indicam que combinações específicas de mutações do gene GJB2 existem em populações diferentes ${ }^{(38)}$.

A falta de informações precisas por parte da família acerca de intercorrências durante a gestação, o parto e o período perinatal costumam dificultar o diagnóstico etiológico nos casos de surdez de origem ambiental. Assim, é provável que casos de origem não genética acabem sendo rotulados como sendo de origem indefinida.

No entanto, a precisa identificação da causa genética ainda apresenta dificuldades, pela variedade fenotípica. Há a necessidade, primeiro, de se excluir as causas não-genéticas, depois as sindrômicas para, somente então, procurar pelas não-sindrômicas ${ }^{(39)}$.

Atualmente, o teste genético está clinicamente disponível no Brasil para um limitado número de genes, mas esta situação se modificará em um futuro próximo à medida que as pesquisas nesta área evoluam e que as triagens gênicas laboratoriais mais efetivas sejam desenvolvidas ${ }^{(40)}$.

A cada dia surgem novos casos de perda auditiva em que são encontradas mutações no gene da Conexina $26^{(35)}$, pois de uma forma geral, indivíduos homozigotos para mutações no gene da Conexina 26 apresentam surdez pré-lingual profunda, embora ao nascimento o fenótipo possa variar de audição normal a surdez profunda ${ }^{(3)}$.

$\mathrm{O}$ uso de testes moleculares em conjunto com a Triagem Auditiva Neonatal poderá ajudar na detecção precoce da surdez infantil. Além disso, é possível hoje até mesmo a detecção de indivíduos com mutações no gene da Conexina 26, porém ainda sem manifestação da perda auditiva. As consequências dessa predição, no âmbito social e familial, são significativas, seja em relação à prevenção da surdez, seja no auxílio e redução dos custos da educação especial desses indivíduos, seu tratamento médico e decisão profissional ${ }^{(13)}$.

Por esta razão, estudos sugerem que o teste genético seja incluído na bateria de testes na investigação de perdas auditivas neurossensoriais $^{(15,18-19)}$ como complemento à Triagem Auditiva Neonatal ${ }^{(22)}$. 


\section{COMENTÁRIOS FINAIS}

A mutação 35delG do gene da Conexina 26 está potencialmente vinculada a casos de perda auditiva não esclarecida. A pesquisa desta mutação pode ser incluída na bateria de exames de investigação etiológica da surdez indeterminada, uma vez que auxilia no diagnóstico precoce e possibilita, em caso de positividade, o aconselhamento genético. Em pacientes com suspeita de doença hereditária o estudo em outros genes deve ser efetuado.

Os esforços para o diagnóstico precoce da deficiência auditiva infantil, além da Triagem Auditiva Neonatal, poderiam incluir a triagem das mutações genéticas associadas à surdez.

\begin{abstract}
In the last few years, great progress has been made in the search for genes associated to hereditary hearing impairment, allowing more precise and earlier diagnosis. Connexin 26 gene mutations (GJB2 - Cx26) cause hearing impairment. Due to the easiness and benefits of the screening of mutations on the gene GJB2, genetic testing is becoming an important resource in public health. The aim of the present study was to conduct a literature research about the mutation of the Connexin 26 gene and its influence in hearing. It was carried out a literature review through electronic search using the keywords: hearing loss, genetics, genetic screening, and Connexin 26, at the databases MEDLINE, SciELO and LILACS, from the 90s to the present days. The results indicate that the 35delG mutation of Connexin 26 is potentially associated to some cases of hearing loss that were not justified. The research regarding this mutation could be included in the battery of tests for etiologic investigation of undetermined deafness, possibly elucidating the etiology of some cases and allowing genetic counseling.
\end{abstract}

Keywords: Hearing loss/genetics; Deafness/genetics; Screening genetics; Mutation; Connexins/genetics

\title{
REFERÊNCIAS
}

1. Sartorato EL, Guerra ATM. Genes do silêncio: a complexidade clínica da surdez genética. Rev Bras Otorrinolaringol. 2002;68(6):903-6.

2. Smith RJ, Hone S. Genetic screening for deafness. Pediatr Clin North Am. 2003;50(2):315-29. Review.

3. Pfeilsticker LN, Stole G, Sartorato EL, Delfino D, Guerra ATM. A investigação genética na surdez hereditária não-sindrômica. Rev Bras Otorrinolaringol. 2004;70(2):182-6.

4. Kelsell DP, Dunlop J, Stevens HP, Lench NJ, Liang JN, Parry G, et al. Connexin 26 mutations in hereditary non-syndromic sensorineural deafness. Nature. 1997;387(6628):80-3. Comment in: Nature. 1998;394(6694):630-1.

5. Wilcox SA, Saunders K, Osborn AH, Arnold A, Wunderlich J, Kelly T, et al. High frequency hearing loss correlated with mutations in the GJB2 gene. Hum Genet. 2000;106(4):399-405.

6. Piatto VB, Maniglia JV, Bertollo EMG. Importância da junção comunicante na fisiologia sensorioneural da cóclea. Acta AWHO. 2001;20(1):46-52.

7. ACMG. Genetics Evaluation Guidelines for the Etiologic Diagnosis of Congenital Hearing Loss. Genetic Evaluation of Congenital Hearing Loss Expert Panel. ACMG statement. Genet Med. 2002;4(3):162-71.

8. Bitner-Glindzicz M. Hereditary deafness and phenotyping in humans. Br Med Bull. 2002;63:73-94.

9. Van Laer L, Cryns K, Smith RJ, Van Camp G. Nonsyndromic hearing loss. Ear Hear. 2003;24(4):275-88. Review.

10. Tekin M, Arnos KS, Pandya A. Advances in hereditary deafness. Lancet. 2001;358(9287):1082-90.

11. Wang HL, Chang WT, Li AH, Yeh TH, Wu CY, Chen MS, Huang PC. Functional analysis of connexin-26 mutants associated with hereditary recessive deafness. J Neurochem. 2003;84(4):735-42.

12. Bernardes R, Bortoncello S, Christiani TV, Sartorato EL, Silva RC, Porto PRC. Estudo molecular em crianças candidatas e submetidas ao implante coclear. Rev Bras Otorrinolaringol. 2006;72(3):333-6.

13. Sobe T, Vreugde S, Shahin H, Berlin M, Davis N, Kanaan M, et al. The prevalence and expression of inherited connexin 26 mutations associated with nonsyndromic hearing loss in the Israeli population. Hum Genet. 2000;106(1):50-7.
14. Petersen MB, Willems PJ. Non-syndromic, autosomal-recessive deafness. Clin Genet. 2006;69(5):371-92. Review.

15. Cohn ES, Kelley PM. Clinical phenotype and mutations in connexin 26 (DFNB1/GJB2), the most common cause of childhood hearing loss. Am J Med Genet. 1999;89(3):130-6.

16. Shibata Y, Kumai M, Nishii K, Nakamura K. Diversity and molecular anatomy of gap junctions. Med Electron Microsc. 2001;34(3):153-9.

17. Kikuchi T, Adams JC, Miyabe Y, So E, Kobayashi T. Potassium ion recycling pathway via gap junction systems in the mammalian cochlea and its interruption in hereditary nonsyndromic deafness. Med Electron Microsc. 2000;33(2):51-6.

18. Lefebvre PP, Van De Water TR. Connexins, hearing and deafness: clinical aspects of mutations in the connexin 26 gene. Brain Res Brain Res Rev. 2000;32(1):159-62.

19. Jun AI, McGuirt WT, Hinojosa R, Green GE, Fischel-Ghodsian N, Smith RJ. Temporal bone histopathology in connexin 26-related hearing loss. Laryngoscope. 2000;110(2 Pt 1):269-75.

20. Sartorato EL, Gottardi E, de Oliveira CA, Magna LA, AnnichinoBizzacchi JM, Seixas CA, Maciel-Guerra AT. Determination of the frequency of the 35delG allele in Brazilian neonates. Clin Genet. 2000;58(4):339-40.

21. Oliveira CA, Maciel-Guerra AT, Sartorato EL. Deafness resulting from mutations in the GJB2 (connexin 26) gene in Brazilian patients. Clin Genet. 2002; 61(5):354-8.

22. Piatto VB, Oliveira CA, Alexandrino F, Sartorato EL. Perspectivas para triagem da deficiência auditiva genética: rastreamento da mutação 35delG em neonatos. J Pediatr (Rio J). 2005;81(2):139-42.

23. Van Laer L, Coucke P, Mueller RF, Caethoven G, Flothmann K, Prasad $\mathrm{SD}$, et al. A common founder for the $35 \mathrm{delG}$ GJB2 gene mutation in connexin 26 hearing impairment. J Med Genet. 2001;38(8):515-8.

24. Fitzgerald T, Duva S, Ostrer H, Pass K, Oddoux C, Ruben R, Caggana M. The frequency of GJB2 and GJB6 mutations in the New York State newborn population: feasibility of genetic screening for hearing defects. Clin Genet. 2004;65(4):338-42.

25. Estivill X, Fortina P, Surrey S, Rabionet R, Melchionda S, D'Agruma $\mathrm{L}$, et al. Connexin-26 mutations in sporadic and inherited sensorineural 
deafness. Lancet. 1998;351(9100):394-8. Comment in: Lancet. 1998;351(9109):1131. Lancet. 1998;351(9100):383-4.

26. Stevenson VA, Ito M, Milunsky JM. Connexin-30 deletion analysis in connexin-26 heterozygotes. Genet Test. 2003;7(2):151-4.

27. Belintani Piatto V, Maria Goloni Bertollo E, Lúcia Sartorato E, Victor Maniglia J. Prevalence of the GJB2 mutations and the del(GJB6D13S1830) mutation in Brazilian patients with deafness. Hear Res. 2004;196(1-2):87-93.

28. Oliveira CA, Pimpinati CJ, Alexandrino F, Magna LA, Maciel-Guerra AT, Sartorato EL. Allelic frequencies of the $35 \mathrm{delG}$ mutation of the GJB2 gene in different Brazilian regions. Genet Test. 2007;11(1):1-3.

29. Gasparini P, Rabionet R, Barbujani G, Melchionda S, Petersen M, Brondum-Nielsen $\mathrm{K}$, et al. High carrier frequency of the $35 \mathrm{delG}$ deafness mutation in European populations. Genetic Analysis Consortium of GJB2 35delG. Eur J Hum Genet. 2000;8(1):19-23. Comment in: Eur J Hum Genet. 2001;9(2):151.

30. Green GE, Scott DA, McDonald JM, Woodworth GG, Sheffield VC, Smith RJ. Carrier rates in the midwestern United States for GJB2 mutations causing inherited deafness. JAMA. 1999;281(23):2211-6.

31. Prasad S, Cucci RA, Green GE, Smith RJ. Genetic testing for hereditary hearing loss: connexin 26 (GJB2) allele variants and two novel deafness-causing mutations (R32C and 645-648delTAGA). Hum Mutat. 2000;16(6):502-8.

32. Lucotte G, Mercier G. Meta-analysis of GJB2 mutation 35delG frequencies in Europe. Genet Test. 2001;5(2):149-52.

33. Denoyelle F, Marlin S, Weil D, Moatti L, Chauvin P, Garabédian EN,
Petit C. Clinical features of the prevalent form of childhood deafness, DFNB1, due to a connexin-26 gene defect: implications for genetic counselling. Lancet. 1999;353(9161):1298-303.

34. Marlin S, Feldmann D, Blons H, Loundon N, Rouillon I, Albert S, et al. GJB2 and GJB6 mutations: genotypic and phenotypic correlations in a large cohort of hearing-impaired patients. Arch Otolaryngol Head Neck Surg. 2005;131(6):481-7.

35. Morlé L, Bozon M, Alloisio N, Latour P, Vandenberghe A, Plauchu $\mathrm{H}$, et al. A novel $\mathrm{C} 202 \mathrm{~F}$ mutation in the connexin26 gene (GJB2) associated with autosomal dominant isolated hearing loss. J Med Genet. 2000;37(5):368-70.

36. Löffler J, Nekahm D, Hirst-Stadlmann A, Günther B, Menzel HJ, Utermann G, Janecke AR. Sensorineural hearing loss and the incidence of Cx26 mutations in Austria. Eur J Hum Genet. 2001;9(3):226-30.

37. Rabionet R, Morales-Peralta E, López-Bigas N, Arbonés ML, Estivill X. A novel G21R mutation of the GJB2 gene causes autosomal dominant non-syndromic congenital deafness in a Cuban family. Genet Mol Biol. 2006;29(3):443-5.

38. Abe S, Usami S, Shinkawa H, Kelley PM, Kimberling WJ. Prevalent connexin 26 gene (GJB2) mutations in Japanese. J Med Genet. 2000;37(1):41-3.

39. Piatto VB, Nascimento ECT, Alexandrino F, Oliveira CA, Lopes ACP, Sartorato EL, Maniglia JV. Genética molecular da deficiência auditiva não-sindrômica. Rev Bras Otorrinolaringol. 2005;71(2):216-23.

40. Godinho R, Keogh I, Eavey R. Perda auditiva genética. Rev Bras Otorrinolaringol. 2003;69(1):100-4. 